JURNAL KETAHANAN NASIONAL

Vol. 24, No.2, Agustus 2018, Hal 192-214

DOI:http://dx.doi.org/ 10.22146/jkn.30843

ISSN:0853-9340(Print), ISSN:2527-9688(Online)

Online sejak 28 Desember 2015 di :http://jurnal.ugm.ac.id/JKN

VOLUME 24

No. 2, Agustus 2018

Halaman 192-214

\title{
Optimalisasi Pelaksanaan Kebijakan Pengembangan Kota Layak Anak Dan Implikasinya Terhadap Ketahanan Sosial Masyarakat (Studi Di Kecamatan Gedongtengen, Kota Yogyakarta Provinsi DI Yogyakarta)
}

\author{
Boby Novika \\ Universitas Mohammad Natsir Bukittinggi \\ Email: benovika@gmail.com
}

\begin{abstract}
The purpose of this study was to analyzed the optimization of the implementation of the city development policy and its impact on social resilience of people in Gedongtengen Sub-District, Yogyakarta City.

This type of research was qualitative. Data analysis technique used was descriptive analytical technique. Data collection techniques consisted of two parts: (1) primary data in the form of in-depth interview, observation, documentation; and (2) secondary data in the form of supporting documents, secondary photographs and other data sources from printed and electronic media.

The result of the research showed that the implementation of child friendly city development policy had not been optimally done in Gedongtengen Sub-District of Yogyakarta City. Implementation of policy functions such as preparation, planning, and coaching aspects found a number of obstacles that the implications had not been widespread in the Gedongtengen Sub-District, Yogyakarta. On the other hand, the policy development of child friendly city had the potential to be synergized with youth friendly municipal development policies in Indonesia.
\end{abstract}

Keywords: Optimizing Policy, City of Eligible Children, Social Resilience of Society

\begin{abstract}
ABSTRAK
Tujuan penelitian ini adalah untuk menganalisis optimalisasi pelaksanaan kebijakan pengembangan Kota Layak Anak dan dampaknya terhadap ketahanan sosial masyarakat di Kecamatan Gedongtengen Kota Yogyakarta.

Jenis penelitian ini adalah kualitatif. Teknik analisis data yang digunakan adalah teknik deskriptif analitis. Teknik pengumpulan data terdiri dari dua bagian: (1) data primer berupa wawancara mendalam, observasi, dokumentasi; dan (2) data sekunder berupa dokumen pendukung, foto sekunder serta data lainnya yang bersumber dari media cetak maupun elektronik.

Hasil penelitian menunjukkan bahwa pelaksanaan kebijakan pengembangan Kota Layak Anak belum optimal dilakukan di Kecamatan Gedongtengen Kota Yogyakarta. Pelaksanaan fungsi-fungsi kebijakan seperti aspek persiapan, aspek perencanaan, serta aspek pembinaan menemukan sejumlah kendala sehingga belum berimplikasi luas di Kecamatan Gedongtengen Kota Yogyakarta. Pada sisi yang lain, kebijakan pengembangan Kota Layak Anak memiliki potensi untuk dapat bersinergi dengan kebijakan pengembangan kota layak pemuda di Indonesia.
\end{abstract}

Kata Kunci: Optimalisasi Kebijakan, Kota Layak Anak, Ketahanan Sosial Masyarakat. 
Boby Novika -- Optimalisasi Pelaksanaan Kebijakan Pengembangan Kota Layak Anak dan Implikasinya Terhadap Ketahanan Sosial Masyarakat (Studi di Kecamatan Gedongtengen, Kota Yogyakarta Provinsi DI Yogyakarta)

\section{PENGANTAR}

Kebijakan pengembangan kota yang layak anak di Indonesia sejalan dengan amanah Undang-undang No.23 Tahun 2002 tentang Perlindungan Anak yang diturunkan menjadi Peraturan Menteri Negara Pemberdayaan Perempuan dan Perlindungan Anak Republik Indonesia Nomor 02 Tahun 2009 tentang Kebijakan Kabupaten/Kota Layak Anak.

Pengembangan Kota Layak Anak di Indonesia perlu diapresiasi, sebab memberikan harapan terciptanya generasi muda yang berkualitas, sehat, cerdas, kuat dan ramah. Fokus kebijakan ini menyinergikan pembangunan sumber daya manusia khususnya anak-anak dan remaja selaku generasi muda dengan lingkungan kota yang humanis, dan berperan strategis dalam perencanaan pembangunan manusia Indonesia ke depan.

Kota Yogyakarta merupakan satusatunya kota yang menerapkan kebijakan Kota Layak Anak di Provinsi Yogyakarta. Pemerintah Kota Yogyakarta menerapkan kebijakan Kota Layak Anak melalui Kantor Pemberdayaan Masyarakat dan Perempuan (KPMP) Kota Yogyakarta (http://www.kla. or.id. Diakses 21 Agustus 2014, Pukul 14.00 WIB). Dalam sejarahnya, Pemerintah Kota Yogyakarta telah memulai inisiasi kebijakan pengembangan Kota Layak Anak sejak 2009 dari tingkatan pratama (terendah). Indikator kebijakan pengembangan Kota Layak Anak di Kota Yogyakarta terbagi ke dalam enam bidang (klaster) yaitu, komitmen wilayah, hak sipil dan kebebasan, kesehatan dasar dan kesejahteraan, perlindungan khusus, lingkungan keluarga dan pengasuhan alternatif, serta pendidikan dan pemanfaatan waktu luang. Namun setelah 6 tahun berjalan, implementasi kebijakan pengembangan Kota Layak Anak di Kota Yogyakarta yang berada di bawah koordinasi Kantor Pemberdayaan Masyarakat dan Perempuan (KPMP) Kota Yogyakarta Provinsi DI Yogyakarta belum berjalan secara optimal. Hal ini terlihat dari belum berhasilnya Kota Yogyakarta meningkatkan predikat Kota Layak Anak ke level yang lebih tinggi. Di tingkat nasional, pada tahun 2012 Kota Yogyakarta hanya meraih predikat Kota Layak Anak tingkat madya. Dalam standar pengukuran sebuah Kota Layak Anak, terdapat lima tingkatan, yaitu pratama, madya, nindya, utama dan Kota Layak Anak (Permen PP\&PA No.02 Tahun 2009 tentang Kebijakan Kabupaten/Kota Layak Anak).

Dalam upaya dalam mencapai predikat Kota Yogyakarta menjadi Kota Layak Anak (level tertinggi) pada tahun 2016, Pemerintah Kota Yogyakarta mengembangkan konsep kampung ramah anak (KRA) di setiap RW di seluruh kecamatan yang ada di Kota Yogyakarta. Tujuan pembentukan kampungkampung ramah anak ini adalah untuk menstimulasi pengembangan Kota Layak Anak yang dimulai dari bawah/akar rumput(bottom up). Melalui pembentukan kampungkampung ramah anak tersebut, diharapkan akan mempermudah terbentuknya kelurahan layak anak, kecamatan layak anak hingga menjadi kota yang layak anak. Oleh karena itu, pelaksanaan kebijakan pengembangan kampung layak anak, kelurahan layak anak, serta kecamatan layak anak merupakan rangkaian dari optimalisasi pelaksanaan kebijakan pengembangan Kota Layak Anak di Kota Yogyakarta.

Kota Yogyakarta terdiri dari 14 kecamatan. Salah satu kecamatan yang mendapat sorotan dalam penelitian ini adalah Kecamatan Gedongtengen. Hal ini dikarenakan, realisasi pelaksanaan kebijakan 
di Kecamatan Gedongtengen hingga 2016 merupakan yang terendah dibandingkan dengan kecamatan lainnya di Kota Yogyakarta. Dengan kata lain, terdapat indikasi bahwa pelaksanaan kebijakan di kecamatan tersebut belum optimal dilakukan. Hal tersebut dapat dilihat dari beberapa indikasi sebagai berikut:

Pertama, berdasarkan observasi awal yang peneliti lakukan terlihat bahwa beberapa wilayah di Kecamatan Gedongtengen rentan terhadap permasalahan sosial, seperti wilayah Pajeksan, Sosrowijayan, Dagen dan Jlagran. Kondisi rentan tersebut salah satunya dikarenakan wilayahnya banyak dihuni para pendatang dan menjadi pusat kegiatan bisnis, perekonomian dan wisata di Kota Yogyakarta. Sebagai sebuah kecamatan yang berada di pusat Kota Yogyakarta, dinamika sosial dan interaksi sosial yang disertai beragam tantangan kehidupan bermasyarakat di kecamatan tersebut berjalan sangat kompleks. Berdasarkan wawancara awal peneliti dengan Kepala KPMP Kota Yogyakarta (2014) diketahui bahwa khusus di Kecamatan Gedongtengen, beragam persoalan menyangkut kehidupan sosial masyarakat yang langsung bersentuhan dengan generasi muda menjadi tantangan dalam pengembangan kebijakan ini.

Kedua, berdasarkan data KPMP Kota Yogkarta (2014) tentang rekapitulasi jumlah kecamatan yang mengimplementasikan kebijakan Kota Layak Anak di Kota Yogyakarta, diketahui bahwa Kecamatan Gedongtengen merupakan satu-satunya kecamatan di Kota Yogyakarta yang memiliki kampung ramah anak (KRA) paling sedikit hingga tahun 2014, yakni dua kampung ramah anak yang berada di RW 11 Sosromenduran dan RW 16 Pringgokusuman. Jumlah ini masih sangat minim, mengingat jumlah RW yang terdapat di kecamatan ini sebanyak 36 RW. Pencapaian yang masih minim tersebut mengindikasikan bahwa pengimplementasian kebijakan pengembangan Kota Layak Anak di Kecamatan Gedongtengen, Kota Yogyakarta belum optimal dilaksanakan.

Ketiga, belum optimalnya pelaksanaan kebijakan pengembangan kecamatan layak anak di Kecamatan Gedongtengen juga tidak terlepas dari peningkatan potensi pembangunan fisik di kecamatan ini. Berdasarkan data Dinas Perizinan Kota Yogyakarta pada 2014 diketahui bahwa dari 106 izin permohonan pendirian hotel baru di Yogyakarta, Pemerintah Kota Yogyakarta telah mengeluarkan sebanyak 29 perizinan hotel baru (http://tribunjogja.com, diakses 16 Oktober 2014/ 16:30 WIB). Khusus di Kecamatan Gedongtengen, pengajuan permohonan izin mendirikan hotel pada 2014 berjumlah 21 pengajuan. Jumlah pemohonan perizinan pembangunan hotel di kecamatan ini merupakan yang tertinggi di Kota Yogyakarta bila dibandingkan dengan kecamatan lainnya seperti Kecamatan Gondokusuman (15 permohonan), Mergangsan (11 permohonan), Mantrirejon (10 permohonan) dan kecamatan sisanya berjumlah kurang dari 10 permohonan perijinan. Kondisi ini kontrapoduktif dengan upaya optimalisasi pelaksanaan kebijakan pengembangan kecamatan layak di Kota Yogyakarta. Berdasarkan observasi awal peneliti, di beberapa RW di Kecamatan Gedongtengen, tidak lagi memiliki ruang yang cukup bagi anak dan generasi muda untuk dapat berinteraksi dengan aman dan nyaman.

Penelitian ini diwadahi dengan konsep optimalisasi pelaksanaan kebijakan, Kota Layak Anak, dan ketahanan sosial masyarakat.

Kebijakan sosial erat kaitannya dan berhubungan langsung dengan semua komponen masyarakat. Dalam hal ini, 
kebijakan Kota Layak Anak merupakan bagian dari kebijakan sosial yang dijalankan pemerintah. Menurut hemat peneliti, kebijakan Kota Layak Anak dapat dipandang sebagai bagian dari pencapaian tujuan ketahanan sosial karena berisi perencanaan dan pengelolaan suatu lingkungan kondisi kota yang sangat berpengaruh terhadap pembangunan karakter dan kehidupan sosial generasi muda di tengahtengah masyarakat.

Kebijakan berisi pilihan, pertimbangan, kajian dan perumusan yang tepat tentang apa yang akan dilakukan maupun apa yang tidak dilakukan pemerintah. Hosio (2007) mengemukakan bahwa kebijakan merupakan garis pedoman untuk pengambilan keputusan. Selain itu, kebijakan lahir sebagai hasil dari pertimbangan segala peluang dan kemungkinan. Dalam konteks publik, kebijakan yang dimaksud merupakan kebijakan yang diambil oleh pemerintah yang memiliki efek langsung maupun tidak langsung kepada publik. Kebijakan publik memiliki dua kateristik: (1). Kebijakan publik merupakan sesuatu yang mudah untuk dipahami, karena maknanya adalah hal-hal yang dikerjakan untuk mencapai tujuan nasional; dan (2). Kebijakan publik merupakan sesuatu yang mudah diukur, karena ukurannya jelas yakni sejauh mana kemajuan pencapaian cita-cita sudah ditempuh (Nugroho, 2012). Ringkasnya, kebijakan publik dapat dipahami sebagai apa yang dinyatakan dan dilakukan oleh pemerintah, atau tidak dilakukan oleh pemerintah. Kebijakan publik merupakan kebijakan yang dibuat oleh pejabat publik dan memberikan efek secara langsung maupun tidak langsung terhadap publik. Dalam pemahaman lain, kebijakan publik juga dapat dipahami sebagai kebijakan yang dibuat oleh penjabat publik dalam rangka mencapai tujuan-tujuan publik (Nugroho, 2012).

Sebagaimana yang dikemukakan di atas, kebijakan berisi rumusan, strategi, serta proses dalam pengimplementasiannya. Artinya, sebuah kebijakan dikatakan berhasil apabila diimplementasikan terlebih dahulu. Dalam hal ini, sebuah implementasi kebijakan dapat dipahami sebagai upaya penyediaan sarana untuk melaksanakan suatu kebijakan dan dapat menimbulkan dampak terhadap sesuatu Pada sisi lain, implementasi juga dimaknai sebagai to provide the means for carrying out; to give practical effect to (untuk menyediakan; untuk mendorong tindakan yang akan memberikan dampak (Hosio, 2007). Dari sini dapat diambil pemahaman bahwa sebuah implementasi kebijakan merupakan serangkaian langkah dalam menyediakan alat dan sarana untuk mencapai tujuan sebuah kebijakan.

Setelah kebijakan diimplementasikan, sebuah kebijakan perlu memperhatikan sisi optimalisasi. Tidak jarang sebuah kebijakan publik hanya berjalan di tempat setelah sekian lama tanpa perkembangan yang berarti. Upaya meningkatkan potensi keberhasilan sebuah implementasi ini disebut optimalisasi. Optimalisasi lebih banyak dipahami sebagai metode matematika yang menyangkut pengertian memaksimalkan atau meminimalkan fungsi (Gill, 1993).

Optimalisasi memiliki 2 dimensi utama yaitu fungsi tujuan (objective function) dan serangkaian kendala (constraint) (Gill, 1993). Fungsi tujuan berisi kriteria yang ingin dicapai oleh sistem, sedangkan sisi kendala merupakan proses/sistem yang sedang didesain atau diamati. Dalam problem optimalisasi diusahakan untuk memaksimalkan ataupun meminimalkan suatu besaran spesifik sebagai tujuan (objective), yang tergantung dari input sejumlah variabel 
keputusan Dengan demikian, sebuah kebijakan dapat dioptimalkan dengan memperhatikan kondisi riil di lapangan saat kebijakan diimplementasikan. Artinya, perlu diperhatikan apakah kebijakan tersebut diimplikasikan dengan menghadapi serangkaian kendala atau pada kondisi sebaliknya, kebijakan berjalan tanpa kendala. Pada kedua situasi tersebut, terdapat pendekatan berbeda dalam upaya memaksimalkan variabel keputusan yang akan menunjang keberhasilan pencapaian tujuan kebijakan.

Berkaitan dengan kebijakan pengembangan kecamatan layak anak, sejatinya sebuah kebijakan yang diambil oleh pemegang kebijakan merupakan sebuah pilihan yang dipilih untuk diimplementasikan. Di dalamnya berisi beragam program, kegiatan dan serangkaian tindakan yang membutuhkan upaya optimal guna mencapai hasil terbaik yang diinginkan. Sebagaimana yang disebutkan Nugroho, Dye dan Gill di atas, dapat dipahami bahwa kebijakan pengembangan kecamatan layak anak di tingkat kecamatan merupakan bentuk dari kebijakan publik karena dijalankan oleh pejabat publik dan memiliki efek terhadap publik. Di dalamnya berisi tindakan yang dapat mendorong tercapainya optimalisasi kebijakan.

Kebijakan tersebut diarahkan untuk tercapainya ketahanan sosial masyarakat, yang merupakan bagian dari ketahanan nasional. Lemhannas (1994) mengemukakan pengertian ketahanan nasional adalah sebagai berikut.

"Kondisi dinamik bangsa Indonesia meliputi segenap aspek kehidupan nasional yang terintegrasi berisi keuletan nasional, ketangguhan yang mengandung kemampuan mengembangkan kekuatan nasional dalam menghadapi dan mengatasi segala tantangan, ancaman, hambatan, dan gangguan, baik yang datang dari dalam maupun yang datang dari luar.”

Berangkat dari pengertian tersebut, dapat dipahami bahwa ketahanan nasional berisi pandangan ideal tentang bangsa Indonesia. Di dalamnya mencakup 8 aspek yang terdiri dari dua dimensi utama yakni dimensi statis dan dimensi dinamis. Dimensi statis merupakan unsur ketahanan nasional yang sifatnya tetap dan tidak berubah seperti geografi, sumber kekayaan alam dan demografi. Sementara itu, aspek dinamis merupakan unsur ketahanan nasional yang sifatnya bisa berubah sewaktuwaktu seperti ideologi, ekonomi, politik, sosial-budaya, serta pertahanan dan keamanan. Kedelapan bidang tersebut dikenal dengan istilah astagatra ketahanan nasional.

Berkaitan dengan konsepsi ketahanan nasional, maka dalam pencapaian kondisi yang ulet dan tangguh, dibutuhkan serangkaian kebijakan yang mampu mendorong terciptanya ketahanan nasional di segala bidang. Salah satu kebijakan yang dimaksud menyangkut kebijakan sosial.

Dalam pengimplementasiannya, kebijakan publik dimaksudkan untuk mencapai tujuan-tujuan publik dan sudah pasti bersinggungan langsung dengan publik (Nugroho, 2012). Salah satu implikasi yang ditimbulkan oleh kebijakan publik yang diimplementasikan adalah untuk mewujudkan ketahanan sosial. Dalam Keputusan Menteri Sosial Republik Indonesia No.12/HUK/2006 tentang Model Pemberdayaan Pranata Sosial, dalam mewujudkan masyarakat berketahanan sosial, dikemukakan pengertian ketahanan sosial masyarakat sebagai berikut.

"Kemampuan komunitas/masyarakat mengatasi resiko akibat perubahan ekonomi dan politik. Suatu komunitas/masyarakat memiliki ketahanan sosial bila: mampu 
Boby Novika -- Optimalisasi Pelaksanaan Kebijakan Pengembangan Kota Layak Anak dan Implikasinya Terhadap Ketahanan Sosial Masyarakat (Studi di Kecamatan Gedongtengen, Kota Yogyakarta Provinsi DI Yogyakarta)

melindungi secara efektifanggotanya termasuk individu dan keluarga yang rentan; mampu melaksanakaninvestasi sosial dalam jaringan sosial; mampu mengembangkan mekanisme yangefektif dalam mengelola konflik dan kekerasan; serta mampu memelihara kearifanlokal dalam mengelola sumber daya alam dan sosial" (Rahayu, 2014).

Dalam konteks Kota Yogyakarta, kebijakan pembangunan kota yang diimplementasikan oleh Pemerintah Kota Yogyakarta tidak bisa dilepaskan dari kebijakan dalam aspek kepariwisataan. Hal ini dikarenakan Yogyakarta memiliki banyak tempat pariwisata yang berdampak pada dinamika ketahanan sosial masyarakat. Sebagaimana dikemukakan Saryani (dalam Jurnal Ketahanan Nasional, Vol. XIX. No. 1 Edisi April 2013), disebutkan bahwa

"sebagai daerah tujuan wisata, Yogyakarta memiliki akomodasi yang cukup memadai, seperti hotel berbintang 5 sampai 1 sebanyak 14 buah dengan jumlah kama sebanyak 1642, hotel melati sebanyak 126 hotel dengan jumlah kamar sebanyak 1879, kondisi ini belum termasuk pondok wisatanya. Sarana penunjang pariwisata juga tersedia, misalnya biro perjalanan wisata sebanyak 113 buah, restoran 4 buah, rumah makan dengan tipe A berjumlah 38 , restoran tipe $B$ sebanyak 60 sedangkan restoran tipe $C$ sebanyak 73, café sebanyak 24 buah".

Berdasarkan kondisi tersebut di atas, Propinsi Daerah Istimewa Yogyakarta memiliki tingkat pertumbuhan yang baik serta memiliki kemampuan yang tangguh dalam menghadapi berbagai tantangan yang kompleks. Besarnya tingkat urbanisasi dan lancarnya arus informasi, komunikasi serta transportasi telah membuat daerah ini mempunyai kemampuan tinggi dalam menghadapi segala macam tantangan, ancaman dan gangguan.

Namun demikian, tingkat ketangguhan dan kemampuan suatu wilayah dalam menghadapi segala ancaman, tantangan dan gangguan jelas mengalami perubahan dari waktu ke waktu. Terlebih keberadaan Kecamatan Gedongtengen yang notabene berada di pusat Kota Yogyakarta dengan penduduk yang beragam serta peruntukan pemanfaatan wilayah yang juga beragam, membutuhkan sentuhan kebijakan berbeda. Untuk itu, pengukuran tentang ketahanan sosial masyarakat yang beragam tersebut membutuhkan batasan dan indikator yang jelas.

Dengan demikian, bila mengacu kepada pengertian ketahanan sosial masyarakat sebagaimana dikemukakan di atas, maka dapat dirumuskan empat dimensi/parameter utama dalam pengukuran ketahanan sosial masyarakat. Keempat parameter ketahanan sosial masyarakat tersebut yaitu (1). Perlindungan anggota masyarakat, (2). Partisipasi masyarakat dalam organisasi sosial, (3). Pencegahan dan pengelolaan konflik sosial dan tindakan kekerasan, serta (4). Pemeliharaan kearifan lokal.

Keempat parameter ketahanan sosial masyarakat di atas akan menjadi panduan peneliti dalam mengukur implikasi ketahanan sosial masyarakat terkait optimalisasi pelaksanaan kebijakan kecamatan layak anak di tingkat kecamatan.

Penelitian ini adalah penelitian kualitatif. Teknik pengumpulan data terdiri dari data primer, yaitu wawancara mendalam, observasi dan dokumentasi foto pribadi, dan data sekunder, yaitu dokumen pendukung, foto dari berbagai instansi, serta data pendukung lainnya. Adapun jumlah informan dalam 
wawancara mendalam sebanyak 14 orang yang terdiri dari stakeholders/pihak-pihak yang bersentuhan langsung dengan kebijakan mulai dari tingkat kota hingga tingkat wilayah (RW). Teknik analisis data menggunakan teknik analitis-deskriptif (Moleong, 2002; Nawawi, 2007).

\section{PEMBAHASAN}

\section{Korelasi Kota Layak Anak dan Kota Layak Pemuda}

Menurut Lemhannas RI, ketahanan sosial masyarakat suatu daerah merupakan turunan dari konsepsi ketahanan nasional dalam scope (lingkup) yang lebih kecil yakni ketangguhan dan keuletan sosial masyarakat yang dimiliki oleh suatu daerah. Ketahanan sosial masyarakat memiliki keterkaitan langsung dengan setiap kebijakan yang diambil oleh pejabat publik. Kebijakan yang dimaksud dalam penelitian ini adalah kebijakan pengembangan Kota Layak Anak di tingkat kecamatan.

Pemahaman ketahanan sosial yang berisi kemampuan menghadapi tantangan dan rintangan yang datang dari dalam maupun dari luar sangat erat kaitannya dengan tantangan dan rintangan yang dihadapi generasi muda terhadap perkembangan dan pertumbuhan kota tempat tinggalnya. Lingkungan kota merupakan faktor penentu terbentuknya karakter para generasi muda. Dengan kata lain, kota yang ramah pada anak sebagai generasi muda akan menciptakan pemuda yang ramah pada dirinya sendiri dan lingkungan kota tempat tinggalnya. Pada skala yang lebih luas, keberadaan kota yang layak akan berdampak positif terhadap masa depan generasi muda sebagai salah satu asset bangsa.

Sehubungan dengan penelitian ini yang lebih menekankan kepada kajian kepemudaan, dalam hal ini peneliti melihat bahwa kebijakan pengembangan Kota Layak Anak sangat erat kaitannya dan berhubungan langsung dengan pembangunan sumber daya manusia khususnya generasi muda perkotaan. Tujuan dari kebijakan pengembangan Kota Layak Anak yang dicetuskan pemerintah sejalan dengan amanah Undang-undang No. 23 Tahun 2002 (diperbarui melalui UU No. 35 Tahun 2014 tentang Perlindungan Anak) dan Undang-undang No. 40 Tahun 2009 tentang Kepemudaan. Tujuan yang dimaksud adalah menciptakan generasi muda yang berkualitas di masa depan. Generasi muda yang dimaksud akan sangat ditentukan oleh lingkungan tempat tinggalnya, khususnya di wilayah perkotaan.

Berdasarkan data Sensus Penduduk 2010, diketahui bahwa sepertiga penduduk Indonesia saat ini terdiri dari generasi muda (anak-anak, remaja dan pemuda). Dengan proyeksi pertumbuhan penduduk $1,49 \%$ pertahun, diprediksi pada tahun 2025 jumlah generasi muda di Indonesia akan mencapai $60 \%$ lebih yang dominan berada di wilayah perkotaan (http://www.bps.go.id, diakses Desember 2014). Itu artinya, ketersediaan lingkungan kota yang layak bagi generasi muda (anak dan pemuda khususnya) dimulai dari saat ini menjadi sebuah keharusan dan perlu diperhatikan. Sebuah lingkungan kota yang layak bagi anak turut menentukan terciptanya generasi muda/pemuda/i yang berkualitas di masa yang akan datang.

Pada penekanan lebih lanjut, bonus demografi generasi muda yang dimiliki Indonesia pada 2025, akan sangat ditentukan oleh lingkungan tempat tinggalnya saat ini yang dalam hal ini bonus generasi muda yang dimaksud dominan berada di 
wilayah perkotaan. Kondisi bonus demografi generasi muda yang diramalkan akan terjadi di Indonesia memberikan konsekuensi lain yaitu pengembangan peran pemuda. Sebagaimana yang dimaksud Soekanto (2009) peran merupakan proses yang harus dilalui oleh subyek yang memiliki kedudukan sebagai aktor yang menjalankan peran, sehingga kepentingannya dapat tercapai (dalam Alfaqi, Jurnal Ketahanan Nasional, Vol. 23, edisi Desember 2017). Jelas disebutkan di situ bahwa peran berkenaan dengan proses. Ini artinya, seorang pemuda akan mendapatkan peran di dalam lingkungannya setelah melalui serangkaian proses. Di dalam proses inilah segala macam hadangan dan tantangan akan ditemukan dan menentukan kualitas pemuda itu sendiri.

Pada awal 2015 Indonesia mengembangkan konsep Kota Layak Pemuda di beberapa kota. Dua di antara kota-kota yang menjadi pilot project Kota Layak Pemuda ini adalah Kota Bogor dan Kota Bandung. Adapun indikator Kota Layak Pemuda di Indonesia adalah lingkungan, kreativitas pemuda, kebijakan pemerintah, sikap partisipasi masyarakat, infrastruktur, dan sarana prasarana kepemudaan.

Indikator-indikator tersebut memiliki keterkaitan dengan indikator Kota Layak Anak, khususnya yang berhubungan dengan lingkungan, infrastruktur dan partisipasi masyarakat. Artinya, terdapat sinergi antara indikator kebijakan Kota Layak Anak dengan Kota Layak Pemuda. Di dalam pelaksanaan, idealnya kebijakan Kota Layak Anak dan Kota Layak Pemuda semestinya dikelola secara sinergis oleh Kementerian PPPA dan Kementerian Pemuda dan Olahraga.

\section{Optimalisasi Pelaksanaan Kebijakan}

\section{Pengembangan Kota Layak Anak di Tingkat Kecamatan}

Kehidupan di banyak kota di dunia tidak terlepas dari perkembangan positif maupun negatif. Pada 2012, lebih dari setengah populasi dunia atau sekitar 3,5 milyar jiwa hidup di wilayah perkotaan. Dari jumlah tersebut, satu milyar di antaranya adalah anakanak. Setiap tahunnya, populasi penduduk kota di dunia akan terus meningkat mencapai 60 juta jiwa pertahun. Pada tahun 1998, sekitar $60 \%$ kelahiran anak-anak di dunia terdapat di perkotaan. Pada 2050, diprediksi sekitar 7 dari 10 orang akan hidup dan tinggal di wilayah perkotaan (Paramita, 2014). Pada satu sisi, perkembangan kota menciptakan kehidupan yang semakin maju, transportasi yang semakin berkembang pesat serta penyediaan sarana komunikasi yang semakin modern. Akan tetapi, pada sisi yang lain, kondisi kehidupan di banyak kota di dunia menunjukkan hal yang memprihatinkan.

Di banyak negara, polusi udara di wilayah perkotaan telah menyebabkan kematian dua juta anak berusia di bawah lima tahun. Meningkatnya jumlah sarana dan prasarana transportasi di dunia, juga mengakibatkan terjadinya banyak kasus kecelakaan lalu lintas. Hingga 2012, sekitar 1,3 juta anak muda menjadi korban kecelakaan lalu lintas. Selain itu, saat ini banyak negara berada di dalam garis kemiskinan. Pada 2012, diperkirakan, sekitar sepertiga populasi kota di dunia hidup di lingkungan kumuh, di mana 60\%nya terdapat di Afrika (Paramita, 2014).

Di bidang kesehatan, UNICEF (2014) mencatat beragam penyakit mematikan masih menjadi momok yang menakutkan bagi anakanak di seluruh dunia. Sekitar 8 juta anak pada 2010, meninggal sebelum mencapai usia 5 tahun yang disebabkan oleh penyakit diare, 
pneumonia, serta komplikasi penyakit bawaan lahir. Selain itu, semakin meningkatnya kasus penularan penyakit HIV-AIDS juga telah mengancam keselamatan jiwa anak. Pada 2010, sekitar seperempat kasus HIV di dunia menimpa anak-anak. Kondisi ini semakin diperparah dengan semakin banyaknya anakanak yang menjadi anak jalanan.

Di bidang pendidikan, sekitar sepertiga jumlah anak-anak di dunia saat ini tidak memiliki akte kelahiran. Akibatnya, anakanak yang tidak memiliki identitas resmi tersebut, akhirnya menjadi korban trafficking (perdagangan anak), pekerja jalanan hingga menjadi penjual obat-obat terlarang. Pada 2012, sekitar 2,5 juta pekerja di seluruh dunia adalah korban traffficking. Sebanyak 22\%-25\% di antaranya adalah anak-anak. Kondisi menghawatirkan anak-anak lainnya juga datang dari dunia pendidikan. Di negara berkembang, lebih dari 200 juta anak di bawah usia 12 tahun gagal mencapai pengetahuan optimalnya karena tidak dapat menikmati pendidikan.

Kondisi memprihatinkan sehubungan dengan perkembangan kota dan kehidupan anak-anakjuga terjadi di Indonesia. Berdasarkan data Komisi Nasional Perlindungan Anak (Komnas PA), pada 2012 terdapat 2.637 kasus kekerasan pada anak. Pada 2013, sebanyak 730 kasus kekerasan pada anak tergolong kepada kekerasan seksual. Di bidang kesehatan, pada 2012 tercatat sekitar 900 ribu anak Indonesia termasuk ke dalam kategori gizi buruk (http:// www.metrotvnews.com, diakses 22 November 2014, pukul 13:25 WIB).

Kondisi di atas telah mendorong pemerintah yang dalam hal ini melalui Kementerian Pemberdayaan Perempuan dan Perlindungan Anak RI mencoba mengembangkan konsep Kota Layak Anak di seluruh Indonesia pada 2005. Sasaran dari kebijakan ini adalah semua anak tanpa diskriminasi, baik yang masih berada dalam kandungan sampai berusia 18 tahun. Awalnya, penerapan kebijakan ini mengacu kepada inisiatif Kota Layak Anak yang digagas oleh UNICEF tahun 1996. UNICEF mendefenisikan Kota Layak Anak sebagai sebuah sistem pemerintahan lokal yang berkomitmen pada implementasi Konvesi Internasional mengenai Hak Anak (convention on the rihgts of the child). Dalam perkembangan berikutnya, kebijakan kota layak anak menjadi bagian dari upaya pencapaian sasaran Millenium Developtment Global Programes (MDGS) yakni menyangkut perlindungan anak dan generasi muda khususnya (http:www.kla.co.id, diakses 20 Juni 2014, pukul 13:00 WIB).

Dalam rangka perlindungan hak anak dan generasi muda di wilayah perkotaan tersebutpemerintah telah menyiapkan blueprint kebijakan kota yang ramah terhadap anak. Hal ini tertera dalam Rencana Pembangunan Jangka Panjang Nasional (RPJPN) yang disahkan dalam UU No.17 Tahun 2007 tentang RPJPN 2005-2025. Selanjutnya, RPJPN tersebut diterjemahkan ke dalam program Rencana Pembangunan Jangka Menengah Nasional (RPJMN) dan Rencana Pembangunan Jangka Menengah (RPJMD) di masing-masing provinsi di Indonesia. Kebijakan pengembangan kota yang layak anak di Indonesia sejalan dengan amanah Undang-undang No.23 Tahun 2002 tentang Perlindungan Anak yang diturunkan menjadi Peraturan Menteri Negara Pemberdayaan Perempuan dan Perlindungan Anak Republik Indonesia Nomor 02 Tahun 2009 tentang Kebijakan Kabupaten/Kota Layak Anak. Dalam Peraturan Menteri tersebut, pengertian Kota Layak Anak dijelaskan 
sebagai berikut.

"Kabupaten/Kota Layak Anak yang selanjutnya disebut KLA adalah sistem pembangunan suatu wilayah administrasi yang mengintegrasikan komitmen dan sumber daya pemerintah, masyarakat dan dunia usaha yang terencana secara menyeluruh dan berkelanjutan dalam program dan kegiatan pemenuhan hak anak"

Kebijakan Kota Layak Anak merupakan kebijakan pemerintah pusat yang digagas pertama kali pada tahun 2005. Latar belakang lahirnya kebijakan ini adalah munculnya keprihatinan pemerintah terhadap perlindungan hak anak di Indonesia yang semakin hari semakin terabaikan. Dasar hukum pelaksanaan kebijakan pengembangan Kota Layak Anak dalam rangka perlindungan anak megacu kepada UU No. 23 Tahun 2002 tentang Perlindungan Anak. Di dalam undangundang tersebut dinyatakan:

"Tujuan perlindungan anak adalah untuk menjamin terpenuhinya hak-hak anak agar dapat hidup, tumbuh, berkembang dan berpatrisipasi secara optimal sesuai dengan harkat dan martabat kemanusiaan, demi terwujudnya anak Indonesia yang berkualitas, berakhlak mulia dan sejahtera."

Di dalam PPPA No.11 Tahun 2011 tentang Pedoman Pengembangan Kebijakan Kota Layak Anak disebutkan defenisi KLA sebagai berikut.

"Kabupaten/kota yang mempunyai sistem pembangunan berbasis hak anak melalui pengintegrasian komitmen dan sumberdaya pemerintah, masyarakat dan dunia usaha yang terencana secara menyeluruh dan berkelanjutan dalam kebijakan, program dan kegiatan untuk menjamin terpenuhinya hak anak."
Adapun subyek anak yang dimaksud oleh peraturan tersebut adalah seseorang yang berusia dari 0 sampai 18 (delapan belas) tahun, termasuk anak yang masih dalam kandungan. Pada tahun 2006 Pemerintah Pusat melalui Kementerian Pemberdayaan Perempuan dan Perlindungan Anak mencanangkan model kebijakan kota layak anak di 5 kabupaten/kota se Indonesia yang sekaligus ditunjuk sebagai pilot project kota layak anak di Indonesia. Kelima kota yang ditunjuk adalah Kota Surakarta, Kota Jambi, Kota Sidoarjo, Kota Kutai Kartanegara, dan Kota Gorontalo (http://www.kla.orid/, diakses tanggal 28 Desember 2014, pukul: 17:20 WIB). Dalam perkembangan berikutnya kebijakan pengembangan Kota Layak Anak telah dilaksanakan di hampir seluruh kabupaten/ kota di Indonesia. Terhitung hingga 2014, terdapat lebih dari 140 kabupaten/kota telah mengembangkan kotanya melalui penerapan kebijakan Kota Layak Anak.

Sesuai dengan Peraturan Menteri Negara Pemberdayaan Perempuan dan Perlindungan Anak No. 13 Tahun 2011 tentang Panduan Pengembangan Kabupaten/Kota Layak Anak (selanjutnya disebut KLA), aspekaspek pengembangan KLA meliputi (1). Persiapan, berupa penguatan komitmen wilayah dan pembentukan tim gugus tugas, (2). Perencanaan, berupa pendataan, analisis situasi anak, dan penyusunan rencana aksi daerah, serta (3). Pembinaan, berupa fasilitasi, monitoring, pelaporan, dan evaluasi.

Sebagai bagian dari strategi pengembangan dan peningkatan predikat kebijakan KLA tersebut, Pemerintah Kota Yogyakarta menekankan pengembangan KLA berbasis kampung dengan menjadikan setiap RW di seluruh kecamatan yang ada di Kota Yogyakarta sebagai sasaran utamanya. Program pengembangan kebijakan berbasis 
RW ini disebut program Kampung Ramah Anak (selanjutnya disebut KRA). Penerapan kebijakan pengembangan KLA di Kota Yogyakarta berbasis pada RW ini dimaksudkan untuk menggali potensi wilayah secara massif dalam upaya perwujudan kebijakan KLA di tingkat kota nantinya. Hal ini dikemukakan oleh Lusi:

"Nah kita itu membuat melalui $R W-R W$ dengan istilah kampung ramah anak. Jadi maksud kami ada keseimbangan antara top down dan bottom up gitu, dari pusat seperti ini, dari bawah seperti ini. Program tersebut di Pemkot Yogyakarta pertama kali dengan pilot project di $2 \mathrm{RW}$ kalau tidak salah di
Badran dan Kelurahan Sosrowijayan" (Wawancara 25 November 2014, pukul 13:00WIB).

Hingga 2014, jumlah RW di Kota Yogyakarta yang telah diassesmen untuk menjadi KRA berjumlah 115 RW dengan rincian, yakni tahun 2011 sebanyak $2 \mathrm{RW}$, tahun 2012 (12 RW), tahun 2013 (32) RW, dan tahun 2014 (60 RW). Sebagai alat ukur penerapan kebijakan KRA ini, Pemerintah Kota Yogyakarta melalui Tim Gugus Tugas Kota Layak Anak (KLA) Kota Yogyakarta, menyusun 60 indikator yang dikembangkan dari 31 indikator kebijakan Kota Layak

Tabel 1

Pelaksanaan Kebijakan Pengembangan Kota Layak Anak di Kecamatan Gedongtengen,

Kota Yogyakarta, Provinsi DIY 2015

\begin{tabular}{|c|c|c|c|}
\hline & & & Serangkaian Kendala \\
\hline & & Strategi & \\
\hline & Persiapan & $\begin{array}{l}\text { Penguatan } \\
\text { Komitmen } \\
\text { Wilayah }\end{array}$ & $\begin{array}{l}\text { Telah berjalan, namun belum optimal dilakukan. Belum semua pihak } \\
\text { masyarakat terlibat, baik di tingkat kecamatan, kelurahan maupun } \\
\text { wilayah (RW). Selain itu, sosialisasi kebijakan belum menyeluruh. }\end{array}$ \\
\hline & & $\begin{array}{l}\text { Pembentukan } \\
\text { Tim Gugus Tugas }\end{array}$ & $\begin{array}{l}\text { Belum dilakukan pembentukan Tim Gugus Tugas tingkat Kecamatan } \\
\text { maupun Kelurahan. Sosialisasi belum menyeluruh dan jalur koordinasi } \\
\text { kebijakan langsung dari tingkat kota ke tingkat RW tidak efektif. }\end{array}$ \\
\hline & Perencanaan & Pendataan & $\begin{array}{l}\text { Ada, namun belum maksimal dan tidak mencakup seluruh RW di tingkat } \\
\text { kecamatan. Pendataan yang hanya mengandalkan masukan informasi } \\
\text { dari pihak kelurahan menjadi tidak efektif. Kendala lainnya kekurangan } \\
\text { sumber daya serta tidak adanya basis data yang kuat. }\end{array}$ \\
\hline$\underset{b}{\square}$ & & $\begin{array}{l}\text { Analisis Potensi } \\
\text { Anak }\end{array}$ & $\begin{array}{l}\text { Tidak ada. Penunjukan langsung RW percontohan tidak diikuti sosialisasi } \\
\text { pada RW lain. }\end{array}$ \\
\hline $\begin{array}{l}3 \\
\overline{5} \\
\overline{5}\end{array}$ & & $\begin{array}{l}\text { Penyusunan } \\
\text { Rencana Aksi }\end{array}$ & $\begin{array}{l}\text { Belum ada. Belum semua pihak terlibat proaktif dengan kebijakan baik } \\
\text { di tingkat kecamatan dan kelurahan. Belum adanya pemetaan analisis } \\
\text { anak dan potensi wilayah menjadi penyebab tidak tersusunnya rencana } \\
\text { aksi di tingkat wilayah.. }\end{array}$ \\
\hline Z & & Koordinasi & $\begin{array}{l}\text { Lemah. Koordinasi di tingkat tim internal gugus kota lemah, begitu juga } \\
\text { antara tingkat kota dengan kecamatan dan kelurahan. }\end{array}$ \\
\hline & Pembinaan & Monitoring & $\begin{array}{l}\text { Minim. Tim Gugus Tugas di tingkat kelurahan dan kecamatan tidak } \\
\text { terbentuk sehingga menyebabkan kekurangan sumber daya dalam } \\
\text { monitoring dan tidak ada acuan yang jelas dalam hal pemantauan. }\end{array}$ \\
\hline & & Fasilitasi & $\begin{array}{l}\text { Telah berjalan, namun belum menyentuh semua RW. Tidak ada } \\
\text { pendataan, minimnya dana, serta tanpa analisis potensi anak dan wilayah } \\
\text { membuat fasilitasi tidak maksimal. Bagi RW yang telah menerapkan } \\
\text { Kebijakan KRA, perubahan dan dampak terhadap ketahanan sosial } \\
\text { masyarakat bisa dilihat dan dirasakan. }\end{array}$ \\
\hline & & Evaluasi & $\begin{array}{l}\text { Ada, namun belum maksimal. Di tingkat RW dan keluraan, program } \\
\text { KRA tidak jelas arah dan sasarannya di tingkat kelurahan dan kecamatan } \\
\text { sehingga sulit dievauasi. }\end{array}$ \\
\hline
\end{tabular}

Sumber: Olahan Peneliti, 2015. 
Anak di Indonesia. Dalam penyusunan indikator-indikator tersebut, pemerintah kota mengacu kepada Peraturan Walikota No. 39 Tahun 2013 tentang Perlindungan Perempuan dan Anak Korban Kekerasan Berbasis Gender.

Pelaksanaan kebijakan pengembangan Kota LayakAnak di Kecamatan Gedongtengen, Kota Yogyakarta, Provinsi DIY 2015, ditunjukkan pada tabel 1 berikut.

Berdasarkan tabel 1 tersebut terlihat bahwa setiap aspek pelaksanaan kebijakan memiliki strategi pencapaian tersendiri. Hanya saja, beberapa dari strategi itu tidak dilakukan secara optimal oleh KPMP Kota Yogyakarta. Akibatnya, seluruh varian di dalam fungsi kebijakan menghadapi kendala ketika diterapkan di lapangan.

Pada aspek persiapan (preparing), penguatan komitmen wilayah hanya dilakukan pada saat sosialisasi awal dan tidak melibatkan banyak elemen masyarakat. Pembentukan Tim Gugus Tugas di tingkat kecamatan dan kelurahan juga tidak dilakukan. Hingga 2013, pelaksanaan asesmen KRA di Kota Yogyakarta telah mencapai lebih dari separoh RW dari total keseluruhan RW yang ada di Kota Yogyakarta. Sebagaimana yang dikemukakan Lusi selaku Ketua KPMP Kota Yogyakarta.

"Ya, jadi dari 615 RW itu yang sudah kita asesmen itu sudah separoh lebih mas. Jadi tahun ini habis. Itu asesmen sosialisasi, kita menyampaikan ke masyarakat kemudian meminta data masyarakat supaya menilai dirinya sendiri itu nanti kita lihat oooo ternyata di kota ini hasilnya seperti ini. Tapi ini belum selesai. Ini masih beberapa minggu ini masih ada pertemuan lagi" (Wawancara tanggal 25 November 2014, pukul 13:00WIB).
Berdasarkan hasil wawancara dengan ketua KPMP Kota Yogyakarta di atas, dasar penunjukan RW-RW dalam sosialisasi awal dan bertahap di Kota Yogyakarta hanya dilakukan secara acak. Berikutnya, sosialisasi dilakukan secara bertahap dan berkelanjutan. Hal ini tergambar dalam pernyataan Lusi yang menyebutkan:

"Kalau kemaren yang udah kita asesmen itu mereka yang sudah mengajukan, tetapi yang untuk tahun ini kita ngambil 300. Ooh, jadi dari 615 itu kita ambil 300, itu kita asesmen dari sini. Dasar ngambil 300 itu ya kita acak aja, kita random. O oh, dari ini separoh-separoh, nanti 2016 itu yang belum itu kita undang lagi" (Wawancara tanggal 25 November 2014, pukul:13:00WIB).

Sosialisasi yang dilakukan tersebut menempatkan posisi aparatur kecamatan dan kelurahan sebatas pihak yang hanya menerima informasi/pengumuman bahwa di Kota Yogyakarta akan dijalankan program KRA. Hal ini lah yang menyebabkan sosialisasi kebijakan berjalan satu arah. Lebih lanjut, Lusi menambahkan:

"Kita pemberitahuan mas. Hooh, biasanya kita datang itu mereka juga punya pendampingan dari wilayah seumpama dari kelurahan dan kecamatan" (Wawancara tanggal 25 November 2014, pukul: 13.00WIB).

Dengan demikian, sosialisasi yang dilakukan KPMP Kota Yogyakarta pada awal 2013 lebih ditujukan untuk mencari RW-RW yang dapat dijadikan pilot project pengembangan KRA, termasuk di Kecamatan Gedongtengen. Adapun maksud dari cara tersebut adalah untuk menstimulasi RW-RW lain agar menjadi RW yang ramah anak. Terbentuknya RW-RW yang ramah anak 
diarahkan untuk mempercepat terciptanya kota layak anak di Kecamatan Gedongtengen. Perihal ini, sebagaimana yang dikemukakan Lusi:

"Kalau semua RW kita minta. Cuman kalau $R W$-nya itu mau mengajukan atau ngak, itu kembali lagi kebutuhan wilayah mas. Jadi kita tidak bisa memaksa kamu harus jadi KRA. Jadi kita sudah mengasesmen, kita sudah menjadikan pilot project, ini wilayah ini, wilayah ini. $R W$ ini sudah paparan..Mas ini lho mas, ini lho mbak KRA supaya mereka tertarik atau ndak." (Wawancara tanggal 24 November, pukul 13:00 WIB)

Pemaparan stakeholder kebijakan terkait sosialisasi kebijakan pengembangan Kota Layak Anak melalui pembentukan kampung-kampung ramah anak di Kecamatan Gedongtengen seperti yang dikemukakan di atas, memberikan pengertian bahwa pelaksanaan program KRA belum menjadi fokus pemerintah kota di Kecamatan Gedongtengen. Pernyataan Ketua KPMP Kota Yogyakarta di atas menunjukkan bahwa kebijakan pengembangan Kota Layak Anak bersifat tidak mengikat. Artinya, keputusan akhir pembentukan kampung ramah anak berada di tangan pihak RW. Padahal, pada sisi yang lain, kebijakan Kota Layak Anak sudah menjadi program unggulan Pemerintah Kota Yogyakarta. Hal tersebut terlihat kontraproduktif di dalam pelaksanaan kebijakan.

Selain itu, kebijakan pengembangan Kota Layak Anak praktis baru menyentuh masyarakat di kecamatan tersebut pada awal 2013. Sebelum itu (2007-2013) atau selama lebih kurang 6 tahun kebijakan pengembangan Kota Layak Anak berjalan di Kota Yogyakarta, wilayah-wilayah RW yang ada di Kecamatan Gedongtengen tidak mengenal sama sekali apa itu kebijakan pengembangan Kota Layak Anak (KLA), maupun apa yang dimaksud dengan program Kampung Ramah Anak (KRA). Meskipun selama enam tahun tersebut, terdapat beragam program yang dilakukan oleh pemerintah kota seperti misalnya program kampung hijau, kampung bebas narkoba, kampung bebas asap rokok, yang kesemuanya dapat mendukung kebijakan dan sekaligus merupakan bagian dari indikator penilaian Kota Layak Anak, hal itu tidak pernah diketahui secara detil oleh masyarakat di Kecamatan Gedongtengen.

Pada aspek perencanaan (planning) berupa pendataan, analisis potensi anak serta penyusunan Rencana Aksi Daerah juga tidak terlaksana dengan baik. Matriks di atas menggambarkan bahwa tidak adanya blueprint kebijakan berupa RAD tingkat kecamatan dan kelurahan menyebabkan tidak terbentuknya tim gugus tugas di tingkat kecamatan. Hal tersebut menjadi faktor penyebab pelaksanaan kebijakan belum memberikan dampak signifikan terhadap ketahanan sosial masyarakat di tingkat kecamatan.

Hingga 2014, pendataan semua hal yang menyangkut program KRA hingga ke seluruh wilayah di Kota Yogyakarta berlangsung bertahap. Di rencanakan pada tahun 2015, seluruh proses pendataan selesai dilaksanakan. Target yang ditetapkan yakni pendataan dapat diselesaikan terhadap seluruh RW yang ada di Kota Yogyakarta yang berjumah 615 RW. Lusi melanjutkan:

\footnotetext{
"Ooo ya, jadi dari 615 RW itu yang sudah kita asesmen itu sudah separoh lebih mas. Jadi tahun ini habis" (Wawancara tanggal 24 November 2014, pukul 13:00 WIB).
} 
Sejauh ini, dikarenakan pendekatan awal yang dilakukan KPMP Kota Yogyakarta bersifat penunjukan langsung RW bersangkutan atas usulan pihak kelurahan, maka hanya RW yang telah ditunjuk telah melakukan pendataan. Pencapaian fungsi pendataan lebih mengandalkan data yagn telah dimiliki pihak kelurahan sebelumnya. Seperti yang dikemukakan Subagio:

"Itu juga ditanyakan oleh KPMP, jumlah penduduknya, pemudanya anakanaknya"(Wawancara tanggal 2 Desember 2014, pukul 14:00 WIB).

Berdasarkan penelusuran peneliti, ketika pendataan awal di RW 16 Pringgokusuman dilakukan, anggota Tim Gugus Tugas KLA Kota Yogyakarta mewawancarai ketua RW setempat dan melakukan checklist masingmasing indikator yang dimiliki RW 16 seperti yang tertera dalam formulir indikator KRA. Penunjukan RW 16 Pringgokusuman lebih didasarkan kepada alasan/rekomendasi yang diajukan oleh pihak kelurahan. Hal serupa juga terjadi di Kelurahan Sosromenduran. Salah satu alasan mengapa pihak kelurahan memilih RW 11 di Pajeksan, lebih dikarenakan pertimbangan teknis. Hery mengatakan:

"Iya, saya waktu itu melihat dari data di situ. Saya lihat pas saya mutar-mutar di sana banyak anak kan begitu. Di $R W-R W$ kan begitu" (Wawancara tanggal 27 November 2014, pukul 13:00WIB).

Berangkat dari penjelasan tersebut, terlihat bahwa data yang diperoleh Tim Gugus Tugas Kota di wilayah lebih dikarenakan informasi sepihak dari pihak kelurahan. Sebagai pembanding, peneliti melakukan wawancara dengan pertanyaan serupa terhadap Ketua RW 1 Kelurahan Pringgokusuman.
Pernyataan serupa juga dikemukakan Sumitro ketika ditanyakan apakah sebelumnya Tim Gugus Tugas KLA Kota Yogyakarta telah melakukan pendataan awal di RW 01. Sumitro mengatakan:

"Belum. Baru 3 RW toh, $R W$ 1, 6, 8, tapi kelihatannya yang turun $R W 1$ sama 6. Kemaren kita Pramusrenbang di kelurahan kemaren tanggal 13-18 bulan Desember, kemaren yang menyampaikan LPMP" (Wawancara tanggal 20 Desember 2014, pukul 17:00WIB).

Belum terdatanya wilayah secara menyeluruh membuat KPMP Kota Yogyakarta praktis tidak mengetahui persis situasi riil dan potensi yang dimiliki wilayah khususnya di Kecamatan Gedongtengen. Hal ini juga menyebabkan pelaksanaan KRA di RW 16 Pringgokusuman dan RW 11 Sosromenduran tumpang tindih dengan berbagai kebijakan pemerintah kota yang sedang berjalan di sana, seperti Kampung Hijau, Kampung Bebas Asap Rokok dan Kampung Bebas Narkoba. Hal sebaliknya terjadi di RW 01 dan RW 06 Kelurahan Pringgokusuman yang harus mengidentifikasi wilayahnya sendiri dalam menyusun proposal pengajuan KRA ke pemerintah kota (KPMP Kota Yogyakarta). Justru penunjukan RW 16 Pringgokusuman sebagai KRA sedikit tidak match dengan kebutuhan wilayah, sebab setelah ditelusuri RW 16 Pringgokusuman memiliki jumlah anak-anak dan remaja sedikit. Perihal ini, Subagio mengemukakan:

"Di sini sedikit sekali, jumlahnya sedikit sekali karena ya di sini memang termasuk kampung yang tidak padat. Remajanya sedikit, anak-anaknya pun tidak begitu banyak" (Wawancara tanggal 2 Desember 2014, pukul 14:00 WIB). 
Situasi seperti ini terlihat paradoks. Ketika yang dijadikan sasaran dalam program KRA adalah anak-anak dan generasi muda, justru yang dijadikan pilot project $\mathrm{KRA}$ adalah wilayah yang memiliki sumber daya generasi muda sedikit. Kondisi sebaliknya terdapat di RW 06 dan RW 01 Pringgokusuman yang justru memiliki banyak anak-anak dan remajanya. Jadi, dilihat dari sasaran kebijakan, ada dua hal berbeda mengenai alasan dan dasar penunjukan RW 16 di Kelurahan Pringgokusuman dengan RW 11 di Kelurahan Sosromenduran. Perbedaannya terletak kepada alasan masing-masing lurah dalam melakukan penunjukan. Bila di RW 16 Pringgokusuman alasannya adalah karena berbagai fasilitas pendukung KRA sudah tersedia sebelumnya, maka di RW 11 Sosromenduran alasannya lebih diutamakan karena di sana memang banyak anak-anak dan remaja.

Berdasarkan penelusuran peneliti, Rencana Aksi Daerah (RAD) di tingkat kecamatan maupun kelurahan terkait KRA di Kecamatan Gedongtengen belum ada. Hal menarik juga peneliti temukan ketika menelusuri RAD-KLA di tingkat kota yang dimiliki pemerintah kota. Ternyata sejauh ini RAD-KLA tersebut juga belum ada. Terkait hal ini, Lusi mengatakan:

"Sedang diproses ini, sebelumnya belum, Tahun kemaren udah konsep RAD KRA. Jadi kita sedang mematangkan ini, mestinya tahun ini bisa selesai. Jadi selama ini belum menggunakan RAD, maksudnya konsep aja" (Wawancara tanggal 25 November 2014, pukul 13:00WIB).

Belum adanya RAD-KLA di tingkat kota ini, praktis membuat pengurus KRA di wilayah hanya melakukan perencanaan yang sifatnya tentatif dan parsial. Seperti yang dinyatakan oleh Wahyu mengenai rencana LPMK Kelurahan Pringgokusuman untuk mendorong 21 RW yang belum menjadi KRA di kelurahan tersebut agar lebih proaktif. Dalam rencana pribadinya, Wahyu mengatakan:

"Ini 2015 ini akan ada pergantian RT dan
RW baru. Ini harus dikontrol untuk bisa
meraih target tahun 2016. KRA 22 RW
kampung ini harus selesai 2018 maksimal
sebagai target LPMK dan bikin RPJM
Kelurahan. Kita susun 2014 dan selesainya
2015" (Wawancara 26 November 2014,
pukul 13:00 WIB).

Di sisi lain, Kelurahan Sosromenduran juga belum memiliki RAD-KLA di tingkat kelurahan. Hal ini menjadikan potensi remaja yang ada di sana seperti keberadaan PIKR tidak bersinergi secara kuat dengan kegiatan-kegiatan KRA. Penjelasan terkait hal tersebut dikemukakan Hery, mantan lurah Sosromenduran, yang menyatakan:

\begin{abstract}
"Kalau untuk PIKR emang selama ini pembinaan khusus dalam artian emang tidak banyak. Mereka malah mandiri, dan waktu itu KRA belum bersinergi, belum masuk itu. Ini kan kepengurusan yang berbeda sebetulnya, tapi kan anak-anaknya sama. Trus berjalannya ini nah trus sampai akhirnya saya pindah ini saya tidak ngikutin lagi kegiatannya yang berjalan di sana" (Wawancara tanggal 27 November 2014, pukul 13:00 WIB).
\end{abstract}

Selain rencana aksi daerah (RAD), terkait KLA dan KRA, Kota Yogyakarta juga belum memiliki peraturan pendukung mengenai pendanaan dan perda khusus mengenai KLA. Peneliti menemukan fakta tersebut ketika melakukan wawancara dengan kepala KPMP Kota Yogyakarta. Hal ini terungkap setelah Lusi menyatakan:

\footnotetext{
"Peraturan Daerahnya gak ada, ndak ada. Cuma memang KLA ini dibikin di DPRD tetapi sementara ini kan macet. DPR kan
} 
Boby Novika -- Optimalisasi Pelaksanaan Kebijakan Pengembangan Kota Layak Anak dan Implikasinya Terhadap Ketahanan Sosial Masyarakat (Studi di Kecamatan Gedongtengen, Kota Yogyakarta Provinsi DI Yogyakarta)

baru itu, heehe, ya sama. Jadi untuk Perda ini pada berhenti semua. Kita hanya sebatas Perwal-perwal itu. Jadi kalau Perda itu sudah ada Perwal KLA itu. Inisiasinya malah DPRD. Kita sudah beberapa kali dipanggil berkomunikasi tetapi berhenti" (Wawancara tanggal 25 November 2014, pukul 13:00 WIB).

Pada aspek pembinaan, monitoring, fasilitasi, koordinasi dan konsultasi hanya dilakukan secara sepihak dan satu arah oleh KPMP Kota Yogyakarta pada RW yang telah menjadi KRA. Evaluasi program juga tidak ada sama sekali setelah kebijakan berjala selama kurang lebih dua tahun. Beberapa kendala inilah yang menyebabkan implikasi kebijakan terhadap ketahanan sosial masyarakat tidak dirasakan secara luas dan menyeluruh di seluruh wilayah kecamatan.

Perihal monitoring, peneliti melihat sejauh ini, seluruh elemen masyarakat di masingmasing kelurahan maupun di Kecamatan Gedongtengen belum terberdayakan di dalam satu sistem kebijakan yang integratif. Hal ini terungkap dari wawancara dengan Wahyu selaku Ketua LPMK Kelurahan Pringgokusuman. Sebagai gambaran terkait monitoring yang dilakukan di Kelurahan Pringgokusuman, Wahyu menuturkan:

"Belum ada. Kalau saya supaya diambilkan salah satu tokoh masyarakat untuk bisa menjadi pendamping dan memberi laporan perkembangan permasalahan. Eee itu harus ada. Kalau ada 22 RW yang paling tidak saya harus menarik 7 orang (7 kampung maksudnya). Udah itu intens dia kan selalu berkumpul dengan kita kemudian memantau, kalau itu ada permasalahan supaya dilaporkan" (Wawancara tanggal 26 November 2014, pukul 13:00WIB).

Di Kelurahan Sosromenduran, perihal monitoring juga menjadi sorotan. Sejak program kampung ramah anak diluncurkan, monitoring tim gugus tugas tidak ada. Hal ini tergambar sebagaimana dikatakan Heri selaku Ketua Karang Taruna Kelurahan Sosromenduran:

"Gak da monitoring juga. Trus diadakan monitoring di lapangan, selama ini jarang, minimal ya 1 tahun sekali. Dananya gede lo itu. Wong karang taruna aja gak dapat segitu kok. KT itu kalau dapat sekarang, tahun depannya gak bisa dapat. Kalau pemuda itu turun terus dari dinas sosial. Harusnya KPMP itu gitu. Makanya program KPMP belum jelas, udah terbentuk udah toh" (Wawancara tanggal 25 November 2014, pukul 14:00 WIB).

Guna mendapatkan informasi berimbang, peneliti mencoba melakukan penelusuran informasi kepada pihak KPMP Kota Yogyakarta. Dari sisi pemerintah kota sendiri, KPMP Kota Yogyakarta melakukan pemantauan secara diam-diam ke wilayah. Terkait hal ini, Lusi selaku Ketua KPMP Kota Yogyakarta mengatakan:

"Itu monitoring kita lakukan diam-diam mas" (Wawancara tanggal 25 November 2014, pukul 13:00WIB)

Setelah peneliti melakukan konfirmasi ke wilayah, peneliti menemukan bahwa hal tersebut (baca: monitoring) tidak diketahui oleh masyarakat di wilayah. Penjelasan dari informan masing-masing wilayah ini menjadi masuk akal ketika dalam penelusuran peneliti sebagaimana yang tergambar dalam ulasan di atas, ditemukan fakta bahwa saat ini banyak sekali kendala di lapangan yang tidak diketahui oleh KPMP Kota Yogyakarta seperti pendanaan, fasilitasi, analisis potensi wilayah, serangkaian kendala riil di wilayah, perkembangan anak dan remaja, dan sebagainya. 
Terakhir, salah satu fungsi yang mesti ditingkatkan adalah evaluasi. Berdasarkan pengakuan dari KPMP, peneliti memperoleh informasi bahwa selama 2014 belum ada dilakukan evaluasi terkait program KRA khususnya di Kecamatan Gedongtengen. Lusi menambahkan:

'Setahu saya untuk tahun 2014 ini kita ndak ada evaluasi yang khusus KRA ... apa ada ya..saya lupa" (Wawancara tanggal 25 November 2014, pukul 13:00 WIB).

Dalam penelusuran berikutnya di wilayah, pihak kelurahan dan RW mengatakan pemantauan program KRA yang dilakukan tidak serius dilakukan. Pemantauan seperti yang dimaksud pihak KPMP Kota Yogyakarta juga tidak diketahui secara persis apakah pemantauan kegiatan di wilayah merupakan bagian dari evaluasi KPMP/Satuan Gugus Tugas KLA Kota Yogyakarta terhadap KRA atau tidak.

\section{Implikasinya Terhadap Ketahanan Sosial Masyarakat.}

Sesuai dengan Keputusan Menteri Sosial Republik Indonesia No.12/HUK/2006 tentang Model Pemberdayaan Pranata Sosial Dalam Mewujudkan Masyarakat Berketahanan Sosial, pengertian ketahanan sosial masyarakat dirumuskan sebagai berikut.

"Kemampuan komunitas mengatasi resiko akibat perubahan ekonomi dan politik. Suatu komunitas memiliki ketahan sosial bila: mampu melindungi secara efektifanggotanya termasuk individu dan keluarga yang rentan; mampu melaksanakan investasi sosial dalam jaringan sosial; mampu mengembangkan mekanisme yang efektif dalam mengelola konflik dan kekerasan; serta mampu memelihara kearifan lokal dalam mengelola sumber daya alam dan sosial"
Mengacu kepada konsep ketahanan sosial masyarakat yang dijabarkan di dalam Kepmensos di atas, dapat dirumuskan empat dimensi/parameter utama dalam pengukuran ketahanan sosial suatu komunitas/masyarakat. Keempat parameter ketahanan sosial tersebut, yaitu (1). Dimensi perlindungan anggota masyarakat, (2). Dimensi partisipasi masyarakat, (3). Dimensi pencegahan dan pengelolaan konflik sosial, serta (4). Dimensi pemeliharaan kearifan lokal.

Keempat parameter ketahanan sosial masyarakat tersebut menjadi panduan peneliti dalam mengukur implikasi ketahanan sosial masyarakat terkait optimalisasi pelaksanaan kebijakan Kota Layak Anak di Kecamatan Gedongtengen. Berkenaan dengan fokus pembahasan berupa kajian tentang kepemudaan, maka parameter implikasi kebijakan pengembangan Kota Layak Anak terhadap ketahanan sosial masyarakat di Kecamatan Gedongtengen lebih ditekankan kepada pencapaian indikatorindikator kebijakan pengembangan Kota Layak Anak (KLA) melalui pencanangan program Kampung Ramah Anak (KRA) yang bersinergi dengan bidang kepemudaan di kecamatan tersebut.

Bila ditinjau implikasi yang ditimbulkan dari pelaksanaan kebijakan pengembangan Kota Layak Anak pada beberapa RW yang telah menjalankan program Kampung Ramah Anak (KRA), dapat diketahui bahwa kebijakan pengembangan kecamatan layak anak melalui pelaksanaan program Kampung Ramah Anak di tingkat kecamatan, sejatinya berpotensi memberikan dampak terhadap beberapa aspek ketahanan sosial masyarakat. Pada aspek fasilitasi misalnya, selama dua tahun program Kampung Ramah Anak berjalan di Kecamatan Gedongtengen, terdapat beberapa indikasi 
yang menunjukkan bahwa kebijakan KRA berdampak pada ketahanan sosial masyarakat.

Berdasarkan penelusuran peneliti, kondisi fisik kewilayahan di beberapa RW yang telah menjadi KRA terlihat jauh berbeda dengan kondisi di RW lain. Di sana, kenyamanan dan ketenangan begitu terasa. Kenyamanan dan suasana lingkungan yang asri ini sangat bermanfaat bagi generasi muda. Misalnya, kondisi fisik kewilayahan di RW 16 Pringgokusuman terlihat jauh berbeda dengan kondisi di RW lain. Di sana kenyamanan dan ketenangan begitu terasa. Kenyamanan dan suasana lingkungan yang asri ini sangat bermanfaat bagi generasi muda. Dalam hal ini Puji selaku Sekretaris Karangtaruna Kelurahan Pringgokusuman menuturkan:

"Dari apa ya mas, dari fisiknya. Kalau di KRA mereka punya sarana bermain, ada himbauan, mereka ingin menunjukkan ini lho KRA, eee, sedang di RW yang belum sarana bermain sangat terbatas, kumuh, kurang tertata, yang lainnya belumm. belum. Kalau kenyaman warga KRAnya, nah kalau kenyamanan warga KRA nya gini lho, jadi KRA yang ada di kelurahan itu kebetulan ada di RW 16, nah kebetulan $R W 16$ itu juga menjadi kampung hijau, jadi 2 predikatnya. Di sana itu suasana sudah sangat asri, rindang, nyaman karena bersih, ada himbauan kampung, Kebetulan juga jadi kampung bebas asap rokok, di sana juga sangat nyaman. Kalau saya tinggal di sana juga sangat nyaman. Teduh warna-warni" (Wawancara tanggal 24 November 2014, pukul 19:00 WIB).

Penilaian terhadap dampak positif yang ditimbulkan dari pelaksanaan kebijakan Kampung Ramah Anak di Kecamatan Gedongtengen juga diberikan beberapa pihak lainnya. Salah satunya diungkapkan oleh Kabul selaku Ketua LPMK Kelurahan Sosromenduran. Kabul menuturkan:
.. "di tempat mereka itu dari ketimbang di $R W-R W$ yang lain emang agak lebih nyaman di situ dan warga masyarakatnya itu hepi-hepi gitu lo. Dan sepengetahuan saya tidak ooo ada ee mungkin tidak banyak y a mereka-mereka itu apa itu mereka mudamuda itu tadi senang berbudaya. Kalau kita ada penampilan di Solo, itu mereka itu di KRA yang wakili" (Wawancara tanggal 26 November 2014, pukul 19:00 WIB).

Kenyamanan dan keasrian wilayah RW 16 Pringgokusuman tersebut jelas memberikan dampak positif terhadap perkembangan dan kebutuhan generasi muda untuk berinteraksi. Tempat yang jauh dari kebisingan, polusi dan dilengkapi fasilitas untuk berinteraksi yang cukup merupakan bagian dari indikator Kampung Ramah Anak yang dapat meningkatkan kualitas sumberdaya masyarakat dalam hal ini generasi mudanya

Dilihat dari sisi pendidikan dan kesehatan, banyak indikator KRA yang berkaitan langsung dengan bidang pendidikan, khususnya pendidikan bagi remaja. Pendidikan yang sangat dibutuhkan remaja berkenaan dengan pendidikan reproduksi dan kesehatan remaja. Perhatian yang tinggi terhadap kesehatan ditunjukkan dari pengadaan/ fasilitasi fisik tempat pembuangan asap rokok di setiap rumah, spot publik dan gang jalan RW. Selain itu, terdapat peraturan RW yang mengatur setiap orang yang akan memasuki rumah, wajib mematikan puntung rokoknya di asbak rokok yang tersedia di dinding luar rumah. Hal ini berdampak positif bagi kesehatan generasi muda di sana. Hanya saja, implikasi pelaksanaan kebijakan pengembangan Kota Layak Anak tersebut hanya dapat dilihat hasilnya di RW yang telah maupun yang sedang mengajukan diri menjadi Kampung Ramah Anak (KRA) di Kecamatan Gedongtengen. Adapun 
dampak yang terlihat pada RW yang sedang mengajukan diri sebagai kampung ramah anak juga disebabkan oleh pemberian stimulus/ insentif pembangunan fasilitas sebelumnya oleh KPMP Kota Yoyakarta.

Sejatinya konsep Kota Layak Anak mendorong terbentuknya kelompok masyarakat peduli masalah-masalah sosial. Dampak positif lainnya dari program KRA terhadap generasi muda adalah kebijakan ini secara tidak langsung menghidupkan kembali Karang Taruna di tingkat kelurahan.

Dalam sudut pandang ketahanan sosial masyarakat, kemampuan pencegahan dan pengelolaan konflik sosial juga bisa diartikan sebagai perwujudan kesadaran suatu masyarakat dalam menilai keutuhan wilayah dan penataan keruangan secara proporsional dan menyadari setiap perubahan di wilayahnya akibat perubahan perkembangan pembangunan fisik dari luar. Dalam konteks ini, kondisi objektif kemampuan mawas ke dalam dan mawas ke luar yang dimiliki kecamatan cukup variatif, di mana ada kelurahan yang memiliki kesadaran terhadap wilayah dan internal masyarakatnya cukup tinggi dan ada yang pasif, mengalir begitu saja mengikuti perkembangan zaman.

Namun demikian, dampak dari implementasi kebiijakan pengembangan Kota Layak Anak baru dapat dilihat di RW yang telah menjadi Kampung Ramah Anak saja. Artinya, dampak kebijakan secara lebih luas di seluruh wilayah kecamatan belum dapat dirasakan masyarakat. Hal ini dikarenakan pelaksanaan berbagai fungsi kebijakan di dalam program Kampung Ramah Anak belum berjalan secara maksimal dan belum menyentuh semua wilayah. Peluncuran program Kampung Ramah Anak (KRA) yang dilakukan secara direct command (komando langsung) dari tingkat Pemerintahan Kota ke wilayah (RW) dengan hanya melibatkan pihak kelurahan untuk mengumpulkan data, menjadikan kebijakan ini tidak menyentuh potensi seluruh wilayah secara lengkap. Hal inilah yang kemudian menjadikan program hanya menyentuh sebagian kecil wilayah di tingkat kecamatan. Berikut disajikan proporsionalitas komposisi RW yang telah terlibat maupun yang belum sama sekali terhadap program KRA di Kecamatan Gedongtengen (2013-2015) (Lihat gambar 1).

Gambar 1

Komposisi Jumlah RW Yang Terdampak

Kebijakan Kecamatan Layak Anak Di Kecamatan Gedongtengen

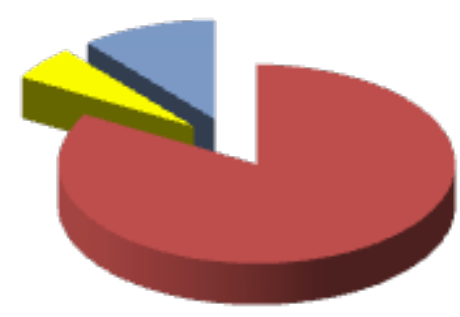

Sumber: Olahan Peneliti, 2015

Keterangan:

*Total RW di Kecamatan Gedongtengen: 36 RW

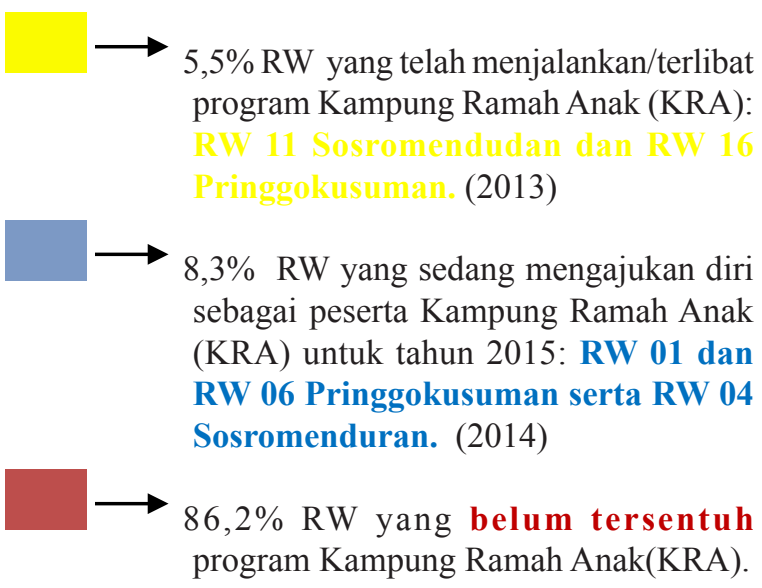

Pada gambar 1 tersebut dapat dilihat bahwa jumlah (RW) yang telah menjadi/ terlibat program KRA hanya 2 RW atau sekitar 5.5\% jumlah keseluruhan RW di 
kecamatan. Sepanjang 2013-2014, sebanyak 3 RW mengajukan diri sebagai peserta program KRA atau sebesar 8,3\%. Sementara itu, lebih dari $80 \%$ RW belum tersentuh kebijakan ini sama sekali. Hal ini jelas merupakan tantangan yang tidak ringan, sebab di dalam target yang dicanangkan Pemerintah Kota Yogyakarta disebutkan bahwa pada tahun 2016 Kota Yogyakarta telah menjadi Kota Layak Anak. Itu artinya, pada tahun 2016 Kota Yogyakarta 'harus telah' memiliki kecamatan-kecamatan yang layak anak, yang notabene dibangun mulai dari tingkat kelurahan layak anak melalui program kampung ramah anak ini.

Dalam pada itu, sebagaimana dikutip dari situs http://www.inilah.com, diakses 7 Juni 2015, diketahui bahwa pada tahun 2015 Indonesia telah mencanangkan pembangunan Kota Layak Pemuda di beberapa kota yang menjadi pilot project seperti Bogor dan Bandung. Indikator Kota Layak Pemuda yang sedang dikembangkan ini mencakup lingkungan, kreativitas pemuda, kebijakan pemerintah, sikap partisipasi masyarakat, infrastruktur, dan sarana prasarana kepemudaan. Jika ditelaah, indikator tersebut juga merupakan bagian dari indikator yang ditetapkan di dalam kebijakan Kota Layak Anak. Di dalam konteks penelitian ini, indikator sikap partisipasi masyarakat merupakan bagian dari indikator ketahanan sosial masyarakat.

Munculnya terminologi Kota Layak Pemuda di Indonesia pada tahun 2015 merupakan terobosan besar. Saat ini, sekitar 30 kota di seluruh dunia telah menjadi Kota Layak Anak (http://www.inilah.com, diakses 7 Juni 2015). Bila dihubungkan dengan kebijakan Kota Layak Anak, sebetulnya ini merupakan dua hal yang saling berkesinambungan. Hanya saja pelaksanaannya di Indonesia membutuhkan penyesuaian. Dijadikannya faktor lingkungan sebagai indikator pertama Kota Layak Pemuda di Indonesia jelas memberikan arahan yang sama dengan kebijakan Kota Layak Anak. Dapat dikatakan bahwa, apapun yang diterima seorang pemuda ketika berusia 25 tahun, akan sangat ditentukan oleh hal apa saja yang diperoleh seorang anak dari lingkungannya ketika berusia 5 tahun.

Pembangunan kapasitas kepemudaan sangat besar artinya bagi pembangunan kota dan perwujudan ketahanan sosial masyarakat. Ada sekian banyak alasan untuk itu. Sebagaimana yang dikemukakan Abdullah, 1974 (dalam Wulandari, Jurnal Ketahanan Nasional, Vol. 23, No. 3, edisi Desember 2017, Hal. 300-309), terdapat beberapa alasan yang menjadikan pembangunan kapasitas pemuda sangat penting dilakukan dalam rangka mewujudkan ketahanan sosial masyarakat:

(1) pemuda memiliki kemurnian idealisme; (2) pemuda cenderung berani dan terbuka dalam menyerap nilai-nilai dan gagasangagasan baru; (3) pemuda memiliki semagat pengabdian dan spontanitas dalam pengabdiannya; (4) pemuda memiliki segudang inovasi dan kreativitas; (5) pemuda memiliki keinginan untuk segera mewujudkan gagasan-gagasan baru; (6) pemuda memiliki keteguhan janji dan keinginan untuk menampilkan sikap dan kepribadian yang mandiri; (7) masih langkanya pengalaman-pengalaman yang dapat merelevansikan pendapat, sikap, dan tindakannya dengan kenyataan yang ada (Abdullah, 1974).

Dengan demikian, peneliti mengambil kesimpulan bahwa kebijakan Kota Layak Anak sebetulnya tidak bisa dipisahkan dari kebijakan Kota Layak Pemuda. Akan lebih tepat disebut bila kebijakan ini merupakan kebijakan yang saling berkelanjutan. Ringkasnya, keberadaan 
Gambar 2

Domain Irisan Kriteria Usia, Lembaga serta Ruang Lingkup Kebijakan Kota Layak Anak dan Kota Layak Pemuda

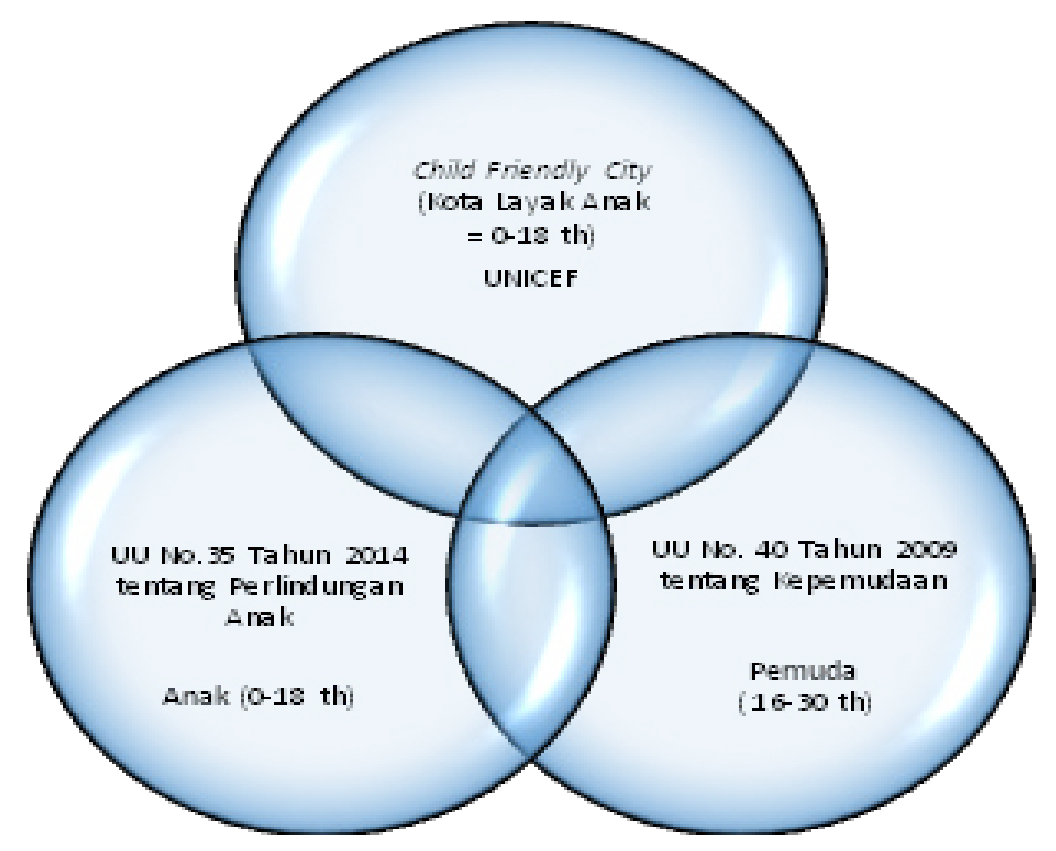

Sumber: Olahan Peneliti, 2015

Child and Youth Friendly City merupakan sebuah konsep yang harus dipadukan di dalam pelaksanaannya. Di Indonesia, kedua kebijakan ini mesti dikerjakan secara terpadu oleh dua lembaga sekaligus yakni Kementerian Negara Pemberdayaan Perempuan dan Perlindungan Anak dan Kementerian Pemuda dan Olahraga. Irisan kebijakan menyangkut kriteria usia anak dan pemuda serta ruang lingkup kebijakan yang tertuang di dalam masing-masing regulasi tersebut dapat dilihat pada gambar 2.

\section{SIMPULAN}

Berdasarkan pembahasan di atas, dapat ditarik simpulan sebagai berikut.

Pertama, pelaksanaan kebijakan pengembangan Kota LayakAnak di Kecamatan Gedongtengen belum optimal dilakukan. Optimalisasi fungsi-fungsi pelaksanaan kebijakan mengalami pelbagai kendala.
Implementasi beberapa varian di dalam fungsi kebijakan seperti pembinaan, monitoring, fasilitasi, koordinasi dan konsultasi masih perlu pembenahan. Pelaksanaan beberapa varian tersebut hanya dilakukan satu arah oleh KPMP Kota Yogyakarta pada RW yang telah menjadi Kampung Ramah Anak. Hal tersebut merupakan penyebab utama belum optimalnya pelaksanaan kebijakan di tingkat kecamatan.

Kedua, kebijakan Kota LayakAnak belum berdampak luas di Kecamatan Gedongtengen sebab Kecamatan Gedongtengen belum memiliki RAD (Rencana Aksi Daerah) di tingkat kecamatan maupun di tingkat kelurahan. Adapun dampak kebijakan terhadap ketahanan sosial masyarakat hanya dapat diamati di RW yang telah menjadi Kampung Ramah Anak (KRA) maupun RW yang sedang mempersiapkan diri menjadi peserta program Kampung Ramah Anak (KRA). 
Ketiga, kebijakan Kota Layak Anak sebetulnya beririsan dengan kebijakan Kota Layak Pemuda yang sudah digulirkan sejak 2015. Implementasi kebijakan Kota Layak Anak maupun Kota Layak Pemuda ke depannya membutuhkan penyesuaian dalam aspek regulasi, kelembagaan dan ruang lingkup kebijakan agar kedua kebijakan kota tersebut dapat bersinergi dan optimal dilaksanakan.

\section{DAFTAR PUSTAKA}

Alfaqi, Mifdal Zusron \& Mujtaba Habibi, Muhammad, 2017, "Peran Pemuda Dalam Upaya Pencegahan Korupsi dan Implikasinya Terhadap Ketahanan Wilayah (Studi Di Kota Yogyakarta, Daerah Istimewa Yogyakarta)", Jurnal Ketahanan Nasional Vol. 23, No.3, edisi Desember 2017, Hal. 320-337.

Anonim, Anak Muda Jogja Harus Sehat, http://www.tribunjogja.com, diakses 4 Desember 2014, pukul 17.30 WIB.

Gill, P.E, Murray W and Wright M.H, 1993, Practical Optimalization, London: Academic Press.

Hosio,2007, Kebijakan Publik\&Desentralisasi, Yogyakarta: Laksbag Yogyakarta.

Lemhannas. 1994. Kewiraan Untuk Mahasiswa. Jakarta:PT.Gramedia Pustaka Utama.

Moleong, 2002, Metodologi Penelitian Kualitatif, Bandung: PT Remaja Rosdakarya.

Nawawi, Hadare, 2007, Metode Penelitian Sosial, Yogyakarta: Gadjah Mada.

Nugroho, Riant, 2012, Public Policy, Jakarta: Elexmedia Komputindo. , 2012, Kebijakan Publik:

Teori dan Proses, Jakarta: Elexmedia
Paramita, Mahditia, 2014, Dari Surakarta Mendesain Kota Layak Anak, Yogyakarta:HRC Yogya

Rahayu, Anizar, 2014 , Ketahanan Sosial Masyarakat, http:// yayasanadministrasiindonesia.com, diakses 5 November 2014, pukul 14:35WIB.

Saryani, 2013, "Pariwisata dan Ketahanan Sosial Budaya", dalam Jurnal Ketahanan Nasional, Vol. XIX No. 1 edisi April 2013, Hal. 47-55.

Unicef, Children in an urban, http://www. childfriendlycities.org, diakses 2 Juni 2014, pukul 15:00WIB.

Wulandari, Prisca Kiki, 2017, "Inovasi Pemuda Dalam Mendukung Ketahanan Ekonomi Keluarga (Studi Di Kampung Warna-Warni Kelurahan Jodipan, Kecamatan Blimbing, Kota Malang)", dalam Jurnal Ketahanan Nasional, Vol 23, No.3, edisi Desember 2017, Hal. 300-319.

\section{Peraturan Perundangan}

Undang-undang No.23 Tahun 2002 tentang Perlindungan Anak

Undang-undang No.17 Tahun 2007 tentang RPJPN 2005-2025.

Undang-undang No. 40 Tahun 2009 tentang Kepemudaan.

Undang-undang No. 35 Tahun 2014 tentang Perlindungan Anak (pembaharuan)

Keputusan Menteri Sosial Republik Indonesia No.12/HUK/2006 tentang Model Pemberdayaan Pranata Sosial dalam Mewujudkan Masyarakat Berketahanan Sosial. 
Peraturan Menteri Negara Pemberdayaan Perempuan dan Perlindungan Anak

Republik Indonesia No. 02 Tahun 2009 tentang Kebijakan Kabupaten/Kota Layak Anak.

Peraturan Menteri Negara Pemberdayaan Perempuan dan Perlindungan Anak Republik Indonesia No.11 Tahun 2011 tentang Pedoman Pengembangan Kebijakan Kota Layak Anak.

Peraturan Walikota Yoyakarta No. 39 Tahun 2013 tentang Perlindungan Perempuan dan Anak Korban Kekerasan Berbasis Gender.

\section{Internet}

http://www.inilah.com, diakses 7 Juni 2015.

http:www.kla.co.id, diakses 20 Juni 2014, pukul 13:00 WIB. http://www.kla.or.id, diakses 21 Agustus 2014, pukul 14:00 WIB.

http://www.metrotvnews.com, diakses 22 November 2014, pukul 13:25 WIB.

http://www.bps.go.id, diakses Desember 2014. http://www.kla.or.id/, diakses tanggal 28 Desember 2014, pukul: 17:20 WIB.

\section{Wawancara}

1. Lusi

2. Subagyo

3. Hery

4. Sumitro

5. Waluyo

6. Puji

7. Kabul 